GRASAS Y ACEITES 70 (4)

October-December 2019, e325

ISSN-L: 0017-3495

https://doi.org/10.3989/gya.1052182

\title{
Synthesis, characterization and evaluation of 1-monoacylglycerols of unsaturated fatty acids as potential bioactive lipids
}

\author{
J. Johny ${ }^{\mathrm{a}}$, A. Jatla ${ }^{\mathrm{b}}$, V.K. Eruva ${ }^{\mathrm{b}}$, S. Misra ${ }^{\mathrm{b}}$ and S.S. Kaki ${ }^{\mathrm{a}, \boldsymbol{凶}}$ \\ ${ }^{\mathrm{a}}$ Centre for Lipid Science \& Technology, \\ ${ }^{\mathrm{b}}$ Applied Biology, CSIR-Indian Institute of Chemical Technology, Uppal Road, Tarnaka, Hyderabad 500007, India. \\ Corresponding author: sskaki@iict.res.in
}

Submitted: 15 October 2018; Accepted: 17 December 2018; Published online: 17 July 2019

SUMMARY: The synthesis of 1-monoacylglycerols of selected unsaturated fatty acids and their antimicrobial and cytotoxicity activity is reported in the present study. The monoacylglycerols of fatty acids like undecenoic, oleic, linoleic and erucic acids were prepared by chemical esterification with solketal followed by deprotection. Fatty acids like alpha linolenic, gamma linolenic and ricinoleic acids were initially isolated from natural sources and further enriched in their respective methyl ester forms. The monoacylglycerols of ricinoleic and linolenic acid methyl esters were prepared by enzymatic transesterification with solketal using lipase from Candida antarctica followed by deprotection. The synthesized 1-monoacylglycerols were purified and characterized by spectral studies. The antimicrobial activity revealed that the monoacylglycerol of gamma linolenic acid was the most effective antibacterial followed by the monoacylglycerols of undecenoic and alpha linolenic acids. In the cytotoxicity assay against five cell lines, all the monoacylglycerols exhibited moderate activity but the activity was best against MCF7 Human Breast Adenocarcinoma cell lines.

KEYWORDS: 1-monoacylglycerols; Antimicrobial activity; Cytotoxicity; Fatty acids; Lipids; Synthesis

RESUMEN: Síntesis, caracterización y evaluación de 1-monoacilgliceroles de ácidos grasos insaturados como potenciales lípidos bioactivos. La síntesis de 1-monoacilgliceroles de ácidos grasos insaturados seleccionados y su actividad antimicrobiana y citotoxicidad se describen en el presente estudio. Los monoacilgliceroles de ácidos grasos como los ácidos undecenoico, oleico, linoleico y erúcico se prepararon mediante esterificación química con solketal seguido de desprotección. Los ácidos grasos como el alfa-linolénico, gamma-linolénico y ricinoleico se aislaron inicialmente de fuentes naturales y se enriquecieron aún más en sus respectivos ésteres metílicos. Los monoacilgliceroles de los ésteres metílicos de los ácidos ricinoleico y linolénico se prepararon mediante transesterificación enzimática con solketal utilizando lipasa de Candida antárctica seguido de desprotección. Los 1-monoacilgliceroles sintetizados se purificaron y caracterizaron mediante estudios espectrales. La actividad antimicrobiana mostró que el monoacilglicerol del ácido gamma-linolénico fue el antibacteriano más eficaz seguido del monoacilglicerol de los ácidos undecenoico y alfa-linolénico. En el ensayo de citotoxicidad contra cinco líneas celulares, todos los monoacilgliceroles mostraron una actividad moderada, pero la actividad fue mejor contra las líneas celulares de adenocarcinoma de mama humano MCF7.

PALABRAS CLAVE: 1-monoacilgliceroles; Ácidos grasos; Actividad antimicrobiana; Citotoxicidad; Lípidos; Síntesis

ORCID ID: Johny J https://orcid.org/0000-0003-3109-5519, Jatla A https://orcid.org/0000-0003-4240-5148, Eruva VK https://orcid.org/0000-0003-1015-3660, Misra S https://orcid.org/0000-0002-3080-7476, Kaki SS http://orcid. org/0000-0003-2726-1166

Citation/Cómo citar este artículo: Johny J, Jatla A, Eruva VK, Misra S, Kaki SS. 2019. Synthesis, characterization and evaluation of 1-monoacylglycerols of unsaturated fatty acids as potential bioactive lipids. Grasas Aceites 70 (4), e 325. https://doi.org/10.3989/gya.1052182

Copyright: (C2019 CSIC. This is an open-access article distributed under the terms of the Creative Commons Attribution 4.0 International (CC BY 4.0) License. 


\section{INTRODUCTION}

Structured lipids have gained importance in specialty foods which include modified lipids ranging from glycerides to phospholipids and are produced for specific food, nutritional and biomedical applications. (Osborn and Akoh 2002). Among these structured lipids, monoacylglycerols (MAGs) are well known for their use as emulsifying agents and as carriers of nutrients in food applications for improved bioavailability ( $\mathrm{Lu}$ et al., 2017). In addition to this, MAGs are also known for their antimicrobial activity and are reported to exert stronger antimicrobial activity than their corresponding free fatty acids (Kabara et al., 2005). In light of the emerging antimicrobial resistance towards conventional antimicrobials, interest in the development of new agents which are non-toxic or less toxic in nature led to interest in alternative agents. In this context, lipids and their derivatives are receiving renewed interest as they are obtained from natural sources and are generally regarded as safe and non-toxic (Littich et al., 2017). Among the bioactive structured lipids, MAGs are known to play an important role as drug carriers in formulations in the cosmetic and pharmaceutical industries (Pawongrat et al., 2008). Among the various MAGs studied, 1-monolaurin is the only MAG which is widely studied and is reported to exert antimicrobial effect as studied by Jon J.Kabara's group and other researchers (Kabara et al., 1972; Altieri et al., 2009). The industrial production of MAGs is carried out by the glycerolysis of natural fats and oils. However, the preparation of structured MAGs can be achieved with different methods by chemical and enzymatic processes which are reported in the literature. These include the glycerolysis of triacyglycerols with glycerol in the presence of inorganic catalysts at high temperatures (Sontag 1982), the reaction of fatty acids and glycidol catalyzed by chromium-fatty acid complexes (Janis et al., 2000) and by enzymatic methods (Bornscheuer 1995).

Research in this area is gaining importance because of the potential benefits of MAGs such as their biocompatibility and biodegradable nature. There are reports on the higher activity of unsaturated fatty acids compared to saturated fatty acids on some microbial strains (Zheng et al., 2005). It was recently reported that long-chain poly unsaturated fatty acids have potential as topical antimicrobials against Gram-positive bacteria along with anti-inflammatory properties (Desbois et al., 2013). Though there are reports on the antimicrobial studies of MAGs of some unsaturated fatty acids, there are no reports on the cytotoxic evaluation of MAGs of unsaturated fatty acids. The objective of the present study is to prepare and characterize the MAGs of selected unsaturated fatty acids and examine their antimicrobial and cytotoxic activities which could expand their application in food and biomedical applications. The unsaturated fatty acids namely undecenoic, oleic, ricinoleic, linoleic, alpha linolenic, gamma linolenic and erucic acids were selected for the study. Undecenoic acid is well known for its antifungal activity and also for its application in pharmaceutical and cosmetic products (Pierard et al., 1997). Oleic acid is known for its emollient properties and is reported to help as a carrier for medicinal and cosmetic ingredients for delivery through the skin (Aarti et al., 1995).

Linoleic acid is a nutritionally important fatty acid whose intake is reported to have inverse effects on heart diseases and cholesterol levels (Maryam et al., 2014). The polyunsaturated fatty acids (PUFAs) ALA and GLA are nutraceutically and physiologically important fatty acids which are known for their numerous nutritional and health benefits. (Flider, 2005; Nguemeni et al., 2013). Erucic acid is mainly obtained from mustard oil, high erucic acid rapeseed oil and is widely known for its industrial applications. Ricinoleic acid, a hydroxyl group containing fatty acid obtained from castor oil is known for many medicinal applications (Pabiś et al., 2016). Owing to the beneficial properties of unsaturated fatty acids, the study of 1-MAGs of these fatty acids could be of interest as they can have potential bioactive applications. Hence the present study was aimed to investigate and evaluate the synthesis and antimicrobial and cytotoxicity activity of 1-MAGs from these selected unsaturated atty acids.

\section{MATERIALS AND METHODS}

\subsection{Materials and instruments}

Oleic and linoleic acids were purchased from TCI chemicals, India. Solketal, erucic acid and borage oil were purchased from Sigma Aldrich. Eripupae were obtained from the Central Silk Board, Bengaluru, India. Castor oil was purchased from a local market. N,N'-Dicyclohexyl carbodiimide (DCC), 4-Dimethylaminopyridine (DMAP) were obtained from SRL. Penicillin and Streptomycin were used as standard drugs. All solvents were purchased from Merck and used without further purification. The proton NMR spectra were recorded on a Varian $400 \mathrm{MHz}$ instrument and TMS was used as internal standard. Mass spectra were recorded using electron spray ionization on a Waters e2695 Separator module (Waters, Milford, MA, USA) mass spectrometer. IR spectra were recorded in dichloromethane on a Perkin-Elmer Fourier transform (FT)-IR Spectrum BX instrument (Model: Spectrum BX; Connecticut, USA). All the synthesized products were purified by silica gel $(60-120$ mesh) column chromatography (Acme Synthetic Chemicals, Mumbai, India) and identified by thin-layer chromatography (TLC). TLC was performed on pre-coated silica gel $60 \mathrm{~F}_{254}$ from Merck (Darmstadt, Germany). 


\subsection{Isolation and enrichment of fatty acids from natural sources}

\subsubsection{Preparation of PUFA fractions from oils}

For gamma linolenic acid and alpha linolenic acid, borage oil and eri silkworm oil were chosen as substrates. Both silkworm oil and borage oils were converted to fatty acid methyl esters according to the reported method. Briefly, the oils were refluxed in a $2 \%$ sulfuric acid-methanol reagent for 3 hours. After complete conversion as monitored by TLC, the solvent was evaporated and the contents were transferred to a separating funnel and ethyl acetate was added and washed with distilled water until neutral. The organic phase was dried over anhydrous sodium sulphate and concentrated to obtain the fatty acid methyl esters (Christie 1982). The resulting methyl esters were subjected to urea crystallization for enrichment of PUFA following previously reported protocols (Kaki et al., 2014).

\subsubsection{Isolation of pure methyl ricinoleate from castor oil}

Castor oil (15 g) was converted to methyl esters using $300 \mathrm{~mL}$ of $2 \%$-sulphuric acid methanol reagent for 3 hours at $75^{\circ} \mathrm{C}$ with magnetic stirring. After complete conversion as monitored by TLC, the solvent was evaporated and the contents were transferred to a separating funnel and ethyl acetate $(150 \mathrm{~mL} \times 2)$ was added and washed with distilled water until neutral. The organic phase was dried over anhydrous sodium sulphate and concentrated to obtain fatty acid methyl esters. The methyl esters $(10 \mathrm{~g})$ were separated into pure methyl ricinoleate (9.04 g; 90\% yield) and nonhydroxy fatty acid methyl esters following a reported protocol (Berdeaux et al., 1997). Castor oil FAME $(10 \mathrm{~g})$ was shaken with $300 \mathrm{~mL}$ hexane and $150 \mathrm{~mL}$ $90 \%$ aq. methanol. After the layers were separated, the methanolic phase was collected and the hexane phase was washed again with fresh $90 \%$ aq. methanol $(100 \mathrm{~mL})$. The two fractions were monitored by TLC for purity of methyl ricinoleate. Finally, methanol was evaporated from the fraction which showed only the presence of methyl ricinoleate and ethyl acetate was added followed by brine and water wash. Later the methyl ricinoleate fraction was dried over anhydrous sodium sulphate and the solvent was evaporated to yield pure methyl ricinoleate with $90 \%$ yield $(9.04 \mathrm{~g})$. The castor oil methyl esters and enriched methyl ricinoleate samples were analyzed by gas chromatography for determining the fatty acid composition.

\subsubsection{Gas chromatography}

Two temperature programs were employed for the gas chromatographic (GC) analysis. For normal fatty acid methyl esters, GC was performed on an Agilent 6890 gas chromatograph equipped with a flame ionization detector. The column used was a DB-225 with a length of $30 \mathrm{~m}, 0.25 \mathrm{~mm}$ i.d and $25 \mu \mathrm{m}$ film thickness. The carrier gas was nitrogen at a flow rate of $1 \mathrm{~mL} / \mathrm{min}$. The oven programming was as follows: $160{ }^{\circ} \mathrm{C}$ for 2 minutes, raised to $230{ }^{\circ} \mathrm{C}$ at a rate of $5^{\circ} \mathrm{C} / \mathrm{min}$ and held at $230{ }^{\circ} \mathrm{C}$ for 20 minutes. The injector and detector temperatures were maintained at 220 and $250{ }^{\circ} \mathrm{C}$, respectively. For castor oil fatty acid methyl esters, GC was performed using an Agilent 6890 gas chromatograph coupled with a FID. A HP-1 capillary column (30 m x $0.25 \mathrm{~mm} \times 0.25 \mu \mathrm{m}$, (Agilent) was used with a column temperature program of $160^{\circ} \mathrm{C}$ for $2 \mathrm{~min}$, raised at $10{ }^{\circ} \mathrm{C} / \mathrm{min}$ to $300{ }^{\circ} \mathrm{C}$ and held for $20 \mathrm{~min}$ at $300{ }^{\circ} \mathrm{C}$. The injector temperature was $280{ }^{\circ} \mathrm{C}$ with a split ratio of $50: 1$. The carrier gas was nitrogen at a flow rate of $1 \mathrm{~mL} / \mathrm{min}$. The detector temperature was $300{ }^{\circ} \mathrm{C}$ with air and hydrogen flow rates of $300 \mathrm{~mL} / \mathrm{min}$ and $30 \mathrm{~mL} / \mathrm{min}$, respectively. The fatty acids were identified by comparing the retention times with those of standard fatty acid methyl esters.

\subsection{Synthesis of 1-monoacylglycerols of unsaturated fatty acids}

\subsubsection{Synthesis of 1-monoacylglycerols}

The synthesis of 1-monoacylglycerols was carried out in two steps following a reported protocol with slight modifications (Yang et al., 2012).

\subsubsection{Esterification of solketal with fatty acids}

The esterification of oleic acid with solketal is described as an example. In a $100 \mathrm{~mL}$ roundbottomed flask, solketal (0.79 g, 0.006 moles) was dissolved in dichloromethane $(15 \mathrm{~mL})$ and DMAP $(0.2 \mathrm{eq}, 0.12 \mathrm{~g})$ was added at $0{ }^{\circ} \mathrm{C}$. A mixture of $\operatorname{DCC}(1 \mathrm{eq}, 1.03 \mathrm{~g})$ and oleic acid $(1 \mathrm{eq}, 1.41 \mathrm{~g}$, 0.005 moles) was added and dissolved in $20 \mathrm{~mL}$ dichloromethane. The ice bath was removed and the reaction was stirred at room temperature for $24 \mathrm{~h}$. After $24 \mathrm{~h}$, the reaction mixture was filtered to remove the precipitate. The filtrate containing the product was washed with saturated aqueous sodium bicarbonate $(50 \mathrm{~mL})$ and water $(3 \times 75 \mathrm{~mL})$ and the organic layer was dried over anhydrous sodium sulphate and concentrated by rotary evaporation at $45^{\circ} \mathrm{C}$ to obtain the crude product. The crude product was purified by silica gel (60-120 mesh) column chromatography using hexane and ethyl acetate gradient to obtain pure acetonide at a $70 \%$ yield $(1.39 \mathrm{~g})$. The product was concentrated and characterized using $1 \mathrm{H}-\mathrm{NMR}$, IR and mass spectral data. A similar protocol was followed for the esterification of undecenoic, linoleic and erucic acids to obtain the corresponding acetonides. 


\subsubsection{Transesterification of ricinoleic acid methyl ester with solketal}

Ricinoleic acid methyl ester (1.5 g; $004.8 \mathrm{mmol})$ and solketal $(0.69 \mathrm{~g} ; 5.28 \mathrm{mmol})$ were mixed together. The lipase from $C$. antarctica $(10 \%$ to wt of substrates) was added and the reaction mixture was magnetically stirred at $60{ }^{\circ} \mathrm{C}$ under vacuum. After maximum conversion as observed by TLC, ethyl acetate was added to the reaction medium and the lipase was separated by filtration. The filtered lipase was washed with ethyl acetate and the combined ethyl acetate filtrate was evaporated to obtain the crude reaction product. The crude product was purified by column chromatography on silica gel (60-120 mesh) using a gradient of hexane and ethyl acetate to obtain pure acetonide at a $73 \%$ yield (1.36 g). Similarly, the ALA methyl ester and GLA methyl esters were transesterified with solketal to obtain the respective acetonides at 45 and $61 \%$ yields, respectively.

\subsubsection{Spectral data of acetonides}

(2, 2-dimethyl-1, 3-dioxolan-4-yl) methyl undec10-enoate (1a); Yield: 60\%; 1H NMR (400 MHz, $\mathrm{CDCl} 3) \delta$ : 1.31 (d, J = $15.7 \mathrm{~Hz},-\mathrm{CH} 3-, 6 \mathrm{H}), 1.50-$ 1.34 (m,-CH2-, 6H), $1.69-1.55$ (m, -CH2-, 2H), $2.08-1.99$ (m, CH2-, 2H), 2.34 (t, J = 15.2 Hz,-CH2-, 2H), $3.74(\mathrm{dd}, \mathrm{J}=8.4 \mathrm{~Hz}, 6.2 \mathrm{~Hz},-\mathrm{CH}-, 1 \mathrm{H}), 4.13-$ 4.05 (m,-CH2- , 2H), 4.17 (dd, J = 11.5Hz, $4.7 \mathrm{~Hz}$, -CH-, 1H), 4.31 (m, -CH-, 1H), 5.06- 4.89 (m,-CH2-, 2H), 5.81 (m, -CH-, 1H); IR (cm-1): $1741 \mathrm{~cm}^{-1}, 2928$, $2855 \mathrm{~cm}^{-1}, 3076 \mathrm{~cm}^{-1} \mathrm{MS}: \mathrm{m} / \mathrm{z} 321.33$ [ $\left.\mathrm{M}^{+} 23\right]$.

(2, 2-dimethyl-1, 3-dioxolan-4-yl) methyl oleate (1b); Yield: 70\%; 1H NMR (400 MHz, CDCl3) $\delta: 0.89(\mathrm{t}, \mathrm{J}=6.72 \mathrm{~Hz}, \mathrm{CH} 3,3 \mathrm{H}), 1.34-1.26(\mathrm{~m}$, (CH2)10, 20H), 1.63 - 1.58 (m, CH2, 2H), 2.03 - 1.98 (m, (CH2)2, 4H), $2.36-2.32(\mathrm{t}, \mathrm{J}=7.4 \mathrm{~Hz}, \mathrm{CH} 2$, $2 \mathrm{H}), 3.75-3.71(\mathrm{~m}, \mathrm{CH}, 1 \mathrm{H}), 4.18-4.05(\mathrm{~m}, \mathrm{CH}$, $\mathrm{CH} 2,3 \mathrm{H}), 4.34-4.28(\mathrm{~m}, \mathrm{CH}, 1 \mathrm{H}), 5.38-5.30$ (m, (=CH) 2, 2H); MS: m/z $419\left[\mathrm{M}^{+} 23\right]$

(9Z,12Z)-(2,2-dimethyl-1,3-dioxolan-4-yl)methyl octadeca-9,12-dienoate (1c); Yield: $90 \%$; 1H NMR (400 MHz, CDCl3) $\delta: 0.89$ (t, J = 8.2 Hz, CH3, 3H), $1.41-1.18(\mathrm{~m},(\mathrm{CH} 2) 9,18 \mathrm{H}), 1.48-1.40(\mathrm{~m}, \mathrm{CH} 2,2 \mathrm{H})$, $1.70-1.59$ (m, CH2, 2H), 2.05 (q, J = 6.8 Hz, CH2, $4 \mathrm{H}), 2.35(\mathrm{t}, \mathrm{J}=6.95 \mathrm{~Hz}, 6.4 \mathrm{~Hz}, \mathrm{CH} 2,2 \mathrm{H}), 2.77(\mathrm{t}, \mathrm{J}=$ $6.5 \mathrm{~Hz}, 2 \mathrm{H}), 3.74(\mathrm{~m}, \mathrm{CH}, 1 \mathrm{H}), 4.38-4.00$ (m, (CH2)2, $4 \mathrm{H}), 5.49-5.24(\mathrm{~m},(\mathrm{CH}) 4,4 \mathrm{H})$; IR: $1735 \mathrm{~cm}^{-1}$, $2875.50 \mathrm{~cm}^{-1}, 2966.43 \mathrm{~cm}^{-1}$; MS: $\mathrm{m} / \mathrm{z}=417.47\left[\mathrm{M}^{+} 23\right]$

(6Z,9Z,12Z)-(2,2-dimethyl-1,3-dioxolan-4-yl) methyl octadeca-6,9,12-trienoate (1d); Yield: 61\%; $1 \mathrm{H} \mathrm{NMR}$ (400 MHz, CDCl3) $\delta: 0.89(\mathrm{t}, \mathrm{J}=6.91 \mathrm{~Hz}$, $\mathrm{CH} 3,3 \mathrm{H}), 1.47-1.31$ (m, (CH2)6, 12H), $1.74-1.59$ (m, CH2, 2H), 2.11-2.03 (m, (CH2)2, 4H), $2.36(\mathrm{t}, \mathrm{J}$ $=7.51 \mathrm{~Hz}, \mathrm{CH} 2,2 \mathrm{H}), 2.96-2.63(\mathrm{~m},(\mathrm{CH} 2) 2,4 \mathrm{H})$, $3.75-3.71(\mathrm{~m}, \mathrm{CH}, 1 \mathrm{H}), 4.44-3.98(\mathrm{~m},(\mathrm{CH} 2) 2,4 \mathrm{H})$, $5.49-5.25(\mathrm{~m},(\mathrm{CH}) 6,6 \mathrm{H})$. IR: $1737 \mathrm{~cm}^{-1}, 2859 \mathrm{~cm}^{-1}$, $2929 \mathrm{~cm}^{-1}, 3013 \mathrm{~cm}-1$; Mass: m/z $415.32\left[\mathrm{M}^{+} 23\right]$
(9Z,12Z,15Z)-(2,2-dimethyl-1,3-dioxolan-4-yl) methyl octadeca-9,12,15-trienoate (1e); Yield: 45\%; $1 \mathrm{H}$ NMR (400 MHz, CDCl3) $\delta 0.97(\mathrm{t}, \mathrm{J}=7.51 \mathrm{~Hz}$, $\mathrm{CH} 3,3 \mathrm{H}), 1.34-1.24$ (m, (CH2)6, 12H), $1.65-1.61$ (m, CH2, 2H), $2.09-2.03(\mathrm{~m}, \mathrm{CH} 2,2 \mathrm{H}), 2.34(\mathrm{t}, \mathrm{J}$ $=7.51 \mathrm{~Hz}, \mathrm{CH} 2,2 \mathrm{H}), 2.86-2.73(\mathrm{~m},(\mathrm{CH} 2) 2,4 \mathrm{H})$, $3.76-3.72$ (m, CH2, 2H), $4.20-4.05$ (m, (CH2)2, $4 \mathrm{H}), 4.37-4.29(\mathrm{~m}, \mathrm{CH}, 1 \mathrm{H}), 5.44-5.27(\mathrm{~m},(=\mathrm{CH}) 6$, $6 \mathrm{H})$; IR: $1265.58 \mathrm{~cm}-1,1736.82 \mathrm{~cm}^{-1}, 2856.53 \mathrm{~cm}^{-1}$, $2930 \mathrm{~cm}^{-1}, 3054.80 \mathrm{~cm}^{-1}$; Mass: $\mathrm{m} / \mathrm{z} 415.28$ [M 23$]$

(Z)-(2,2-dimethyl-1,3-dioxolan-4-yl)methyl docos13-enoate (1f); Yield: 82\%; 1H NMR (400 MHz) $\delta: 0.89(\mathrm{t}, \mathrm{J}=6.78 \mathrm{~Hz}, \mathrm{CH} 3,3 \mathrm{H}), 1.36-1.22$ (m, (CH2)16, 32H), $1.66-1.60(\mathrm{~m}, \mathrm{CH} 2,2 \mathrm{H}), 1.98$ - 2.06 (m, CH2, 4H), 2.34 (t, J = 7.58 Hz, CH2, 3H), 3.69 - 3.78 (m, CH, 1H), 4.37 - 3.99 (m, (CH2)2, 4H), $5.39-5.31(\mathrm{~m},(=\mathrm{CH}) 2,2 \mathrm{H})$; IR: $1733 \mathrm{~cm}^{-1}, 2857$ $\mathrm{cm}^{-1}, 2927 \mathrm{~cm}^{-1}, 3018 \mathrm{~cm}^{-1}$; MS: m/z 475 [M 23$]$

(Z)-(2,2-dimethyl-1,3-dioxolan-4-yl)methyl 12-hydroxyoctadec-9-enoate (1g); Yield: 73\%; $1 \mathrm{H}$ NMR $(500 \mathrm{MHz}, \mathrm{CDCl} 3) \delta 0.88(\mathrm{t}, \mathrm{J}=6.90 \mathrm{~Hz}$, $\mathrm{CH} 3,3 \mathrm{H}), 1.58-1.53$ (m, (CH2)10, 20H), 2.19-2.15 $(\mathrm{m},(\mathrm{CH} 2) 5,10 \mathrm{H}), 2.34(\mathrm{t}, \mathrm{J}=7.58 \mathrm{~Hz}, \mathrm{CH} 2,2 \mathrm{H})$, $3.75-3.72(\mathrm{~m}, \mathrm{CH}, 1 \mathrm{H}), 4.20-4.03(\mathrm{~m}, \mathrm{CH} 2,2 \mathrm{H})$, $4.35-4.27(\mathrm{~m}, \mathrm{CH}, 1 \mathrm{H}), 5.57-5.37(\mathrm{~m},(\mathrm{CH}) 2$, 2H); IR: $1216 \mathrm{~cm}^{-1}, 1733 \mathrm{~cm}^{-1}, 2859 \mathrm{~cm}^{-1}, 2930 \mathrm{~cm}^{-1}$, $3018 \mathrm{~cm}^{-1}, 3348 \mathrm{~cm}^{-1}$; Mass: m/z 435.67 [M 23$]$.

\subsubsection{Hydrolysis of acetonide to 1-monoacylglycerols}

The acetonide of oleic acid (1.25 g, 0.003 moles) dissolved in methanol $(40 \mathrm{~mL})$ in a round-bottomed flask was placed in an ice bath. To this cooled mixture, $2 \mathrm{M}$ aqueous hydrochloric acid ( $2.4 \mathrm{~mL}, 1.6 \mathrm{eq})$ were added in one portion. After $15 \mathrm{~min}$, the ice bath was removed and the reaction mixture was stirred for 5 hours at room temperature $\left(20^{\circ} \mathrm{C}\right)$ while monitoring by TLC at every hour. When the conversion was complete $(5 \mathrm{~h})$, the reaction mixture was diluted with $200 \mathrm{~mL}$ of diethyl ether, transferred to a separating funnel and washed with $200 \mathrm{~mL}$ of saturated aqueous sodium bicarbonate and extracted with diethyl ether $(3 \times 150 \mathrm{~mL})$. The organic phases containing the product were dried over sodium sulphate and concentrated by rotary evaporation at $45^{\circ} \mathrm{C}$. The crude product was purified by silica gel column chromatography using a gradient of hexane and ethyl acetate to obtain the corresponding MAG at a $71 \%$ yield $(0.8 \mathrm{~g})$. The purified product was characterized using $1 \mathrm{H}-\mathrm{NMR}$, IR and mass spectral data. The other acetonides in the study were also hydrolyzed following the same methodology to obtain corresponding monoglycerides.

\subsubsection{Spectral data of 1-MAGs}

2,3-dihydroxypropyl undec-10-enoate (2a; UDAMAG): Yield: 73\%; H1-NMR (400 MHz, CDCl3) $\delta: \delta 1.49-1.18(\mathrm{~m},-\mathrm{CH} 2,12 \mathrm{H}), 2.05-2.00$ 
(m, -CH2-, 2H), $2.45-2.27(\mathrm{~m},-\mathrm{CH} 2-, 2 \mathrm{H}), 3.62-$ $3.58(\mathrm{~m},-\mathrm{OH}, 1 \mathrm{H}), 3.71-3.68(\mathrm{~m},-\mathrm{OH}, 1 \mathrm{H}), 3.94-$ $3.90(\mathrm{~m}, \mathrm{CH}, 1 \mathrm{H}), 4.23-4.12(\mathrm{~m},-\mathrm{CH} 2-, 2 \mathrm{H})$, $5.05-4.87$ (m,-C-H-, 2H), 5.86-5.74(m,-C-H-, 1H); IR: $1729 \mathrm{~cm}^{-1}, 2928 \mathrm{~cm}^{-1}, 2856 \mathrm{~cm}^{-1}, 3015 \mathrm{~cm}^{-1}$, $3407 \mathrm{~cm}^{-1}$; MS: m/z 281.38 [M+23]

2, 3-dihydroxypropyl oleate (2b; Oleic-MAG): Yield: 71\%; H1-NMR (400 MHz, CDCl3) $\delta: 0.89$ $(\mathrm{t}, \mathrm{J}=6.84 \mathrm{~Hz}, \mathrm{CH} 3,3 \mathrm{H}), 1.30-1.26(\mathrm{~m},(\mathrm{CH} 2) 20$, $20 \mathrm{H}), 1.64-1.59(\mathrm{~m}, \mathrm{CH} 2,2 \mathrm{H}), 2.03-1.98$ (m, (CH2)2, 4H), 2.37 - 2.33 (t, $7.59 \mathrm{~Hz}, \mathrm{CH} 2,2 \mathrm{H}), 3.71$ - 3.57 (m, CH2, 2H), 3.95 -3.82 (m, CH, 1H), 4.22 $4.12(\mathrm{~m}, \mathrm{CH} 2,2 \mathrm{H}), 5.38-5.30(\mathrm{~m},(=\mathrm{CH}) 2,2 \mathrm{H})$; IR $\left(\mathrm{cm}^{-1}\right): 1730 \mathrm{~cm}^{-1}, 2851 \mathrm{~cm}^{-1}, 2926 \mathrm{~cm}^{-1}, 3010 \mathrm{~cm}^{-1}$, $3404 \mathrm{~cm}^{-1}$; MS: m/z $379.46\left[\mathrm{M}^{+} 23\right]$

(9Z, 12Z)-2, 3-dihydroxypropyl octadeca-9, 12-dienoate (2c; Linoleic-MAG): Yield: 72\%; H1-NMR (400 MHz, CDCl3) $\delta: 0.89$ (t, 8.2 Hz, $\mathrm{CH} 3, \mathrm{H}), 1.24-1.43(\mathrm{~m},(\mathrm{CH} 2) 7,14 \mathrm{H}), 1.59-1.69$ (m, $\mathrm{CH} 2,2 \mathrm{H}), 2.02-2.11(\mathrm{~m},(\mathrm{CH} 2) 2,4 \mathrm{H}), 2.35(\mathrm{t}, \mathrm{J}=7.6$ $\mathrm{Hz}, \mathrm{CH} 2,2 \mathrm{H}), 2.77$ (t, J = 6.5 Hz, CH, 1H), 3.58$3.72(\mathrm{~m}, \mathrm{CH} 2,2 \mathrm{H}), 3.82-3.96(\mathrm{~m}, \mathrm{CH}, 1 \mathrm{H}), 4.130$ 4.23 (m, CH2, 2H), 5.30 - $5.42(\mathrm{~m},(\mathrm{CH}) 4,4 \mathrm{H})$; IR: $1731.15 \mathrm{~cm}^{-1}, 2856.27 \mathrm{~cm}^{-1}, 2927.96 \mathrm{~cm}^{-1}, 3010.51$ $\mathrm{cm}^{-1}, 3403.57 \mathrm{~cm}^{-1}$; Mass: m/z $377.41\left[\mathrm{M}^{+} 23\right]$

(6Z, 9Z, 12Z)-2, 3-dihydroxypropyl octadeca-6, 9, 12-trienoate (2d; GLA-MAG): Yield: 76\%; 1H NMR (400 MHz, CDCl3) $\delta: 0.89(\mathrm{t}, \mathrm{J}=6.9 \mathrm{~Hz}, 3 \mathrm{H}), 1.47$ $-1.22(\mathrm{~m},(\mathrm{CH} 2) 4,8 \mathrm{H}), 1.73-1.60$ (m, CH2, 2H), 2.11-2.10 (m, (CH2)2, 4H), 2.37 (t, $7.33 \mathrm{~Hz}, \mathrm{CH} 2$, 2H), 2.89-2.72 (m, (CH2)2, 4H), 3.97-3.56 (m, CH, $\mathrm{CH} 2,3 \mathrm{H}), 4.23-4.12(\mathrm{~m}, \mathrm{CH} 2,2 \mathrm{H}), 5.49-5.23$ (m, (CH)6, 6H); IR: $1737 \mathrm{~cm}^{-1}, 2857 \mathrm{~cm}^{-1}, 2927 \mathrm{~cm}^{-1}$, $3011 \mathrm{~cm}^{-1}, 3382 \mathrm{~cm}^{-1}$; Mass: m/z 375.45 [M 23$]$.

(9Z, 12Z, 15Z)-2,3-dihydroxypropyl octadeca-9,12,15-trienoate (2e; ALA-MAG): Yield: 72\%; $1 \mathrm{H}$ NMR (400 MHz, CDCl3) $\delta: 0.97(\mathrm{t}, 7.47 \mathrm{~Hz}$, $\mathrm{CH} 3,3 \mathrm{H}), 1.41-1.27$ (m, (CH2)4, 8H) $1.64-1.60$ (m, CH2, 2H), $2.11-2.03$ (m, (CH2)2, 4H), 2.35 (t, 7.47 Hz, CH2, 2H), $2.90-2.72(\mathrm{~m},(\mathrm{CH} 2) 2,4 \mathrm{H})$, $3.78-3.50$ (m, CH2, 2H), $4.00-3.86(\mathrm{~m}, \mathrm{CH}, 1 \mathrm{H})$, 4.22 - $4.13(\mathrm{~m}, \mathrm{CH} 2,2 \mathrm{H}), 5.50-5.18$ (m, $(\mathrm{CH}) 6$, 6H); IR: $1265.18 \mathrm{~cm}-1,1729 \mathrm{~cm}^{-1}, 2928.70 \mathrm{~cm}^{-1}$, $3056.94 \mathrm{~cm}^{-1}, 3383.57 \mathrm{~cm}^{-1}$; Mass: m/z $375.25\left[\mathrm{M}^{+} 23\right]$

(Z)-2,3-dihydroxypropyl

docos-13-enoate

(2f; Erucic-MAG): Yield: 90\%; 1H NMR (500 $\mathrm{MHz}) \delta 0.88(\mathrm{t}, \mathrm{J}=6.9 \mathrm{~Hz}, \mathrm{CH} 3,3 \mathrm{H}), 1.38-1.20$ (m, (CH2)14, 28H), 1.60-1.66 (m, CH2, 2H), 1.99 $2.01(\mathrm{~m},(\mathrm{CH} 2) 2,4 \mathrm{H}), 2.35(\mathrm{t}, \mathrm{J}=7.6 \mathrm{~Hz}, \mathrm{CH} 2,2 \mathrm{H})$, $3.72-3.58(\mathrm{~m}, \mathrm{CH} 2,2 \mathrm{H}), 3.96-3.90(\mathrm{~m}, \mathrm{CH}, 1 \mathrm{H})$, 4.18 (m, CH2, 2H), A5.50 - 5.09 (m, (=CH)2, 2H); IR: $1730 \mathrm{~cm}-1,2856 \mathrm{~cm}^{-1}, 2927 \mathrm{~cm}^{-1}, 3021 \mathrm{~cm}^{-1}, 3418$ cm-1; Mass: $\mathrm{m} / \mathrm{z}=435\left[\mathrm{M}^{+} 23\right]$

(Z)-2,3-dihydroxypropyl 12-hydroxyoctadec9-enoate (2g; Ricinoleic-MAG): Yield: $80 \% ; 1 \mathrm{H}$ NMR (400 MHz, CDCl3) $\delta 0.89(\mathrm{t}, \mathrm{J}=6.8 \mathrm{~Hz}, \mathrm{CH} 3$, $3 \mathrm{H}), 1.41-1.22(\mathrm{~m},(\mathrm{CH} 2) 8,16 \mathrm{H}), 1.47(\mathrm{t}, \mathrm{J}=6.0$ $\mathrm{Hz}, \mathrm{CH} 2,2 \mathrm{H}), 1.69-1.57$ (m, CH2, 2H), $2.08-2.03$ (m, CH2, 2H), $2.21(\mathrm{t}, \mathrm{J}=6.3 \mathrm{~Hz}, \mathrm{CH} 2,2 \mathrm{H}), 2.35$ (t, $7.45 \mathrm{~Hz}, \mathrm{CH} 2,2 \mathrm{H}), 3.66-3.56$ (m, CH2, 2H), $3.91-3.98(\mathrm{~m}, \mathrm{CH}, 1 \mathrm{H}), 3.96-3.91(\mathrm{~m}, \mathrm{CH}, 1 \mathrm{H})$, $4.23-4.13(\mathrm{~m}, 2 \mathrm{H}, 2 \mathrm{H}), 5.63-5.32(\mathrm{~m},(=\mathrm{CH}) 2$, 2H); IR: $1216 \mathrm{~cm}^{-1}, 1728 \mathrm{~cm}^{-1}, 2858 \mathrm{~cm}^{-1}, 2929 \mathrm{~cm}^{-1}$, $3017 \mathrm{~cm}^{-1}, 3389 \mathrm{~cm}^{-1}$; Mass: m/z 395.22 [M 23$]$.

\subsection{Antimicrobial and cytotoxic studies}

\subsubsection{Antimicrobial activity}

The in vitro antibacterial activity of the newly synthesized compounds was studied against the bacterial strains, Bacillus subtilis (MTCC 441), Staphylococcus aureus (MTCC 96), Staphylococcus epidermidis and Gram-negative organisms viz Escherichia coli (MTCC 443), Pseudomonas aeruginosa (MTCC 741), and Klebsiella pneumoniae (MTCC 618), according to the Agar Well Diffusion Method (Linday 1962). The Nutrient Agar (NA) medium was suspended in distilled water (28 $\mathrm{g}$ in $1000 \mathrm{~mL}$ ) and heated to boiling until it was dissolved completely. The medium and Petri dishes were autoclaved at a pressure of 15 psi for $20 \mathrm{~min}$. The agar well bioassay was employed for testing the antibacterial activity. The medium was poured into sterile Petri dishes under aseptic conditions in a laminar air flow chamber. When the medium in the plates solidified, $0.5 \mathrm{~mL}$ of (week old) of culture from the test organism was inoculated and uniformly spread over the agar surface with a sterile L-shaped rod. Solutions were prepared by dissolving the synthesised 1-MAGs in DMSO and different concentrations were made. After inoculation, wells were scooped out with a $3 \mathrm{~mm}$ sterile cork borer and the lids were replaced onto the dishes. To each well different concentrations of test solutions were added. The controls were maintained. The treated and control samples were kept at $37^{\circ} \mathrm{C}$ for $24 \mathrm{~h}$ in an incubator. Inhibition zones were measured, the diameter was calculated in millimeters and the corresponding results were tabulated.

\subsubsection{Determination of Minimum Inhibitory Concentration}

The minimum inhibitory concentrations (MIC) of various synthetic compounds were tested against three representative Gram-positive organisms viz. Bacillus subtilis (MTCC 441), Staphylococcus aureus (MTCC 96), Staphylococcus epidermidis and Gramnegative organisms viz Escherichia coli (MTCC 443), Pseudomonas aeruginosa (MTCC 741), and Klebsiella pneumoniae (MTCC 618) according to the Microdilution method recommended by CLSI Standard Protocol (Clinical And Laboratory Standards Institute 2008) in a liquid medium (Nutrient agar) distributed in 96-well plates. Serial dilutions of the tested compounds were performed (concentrations from $150 \mu \mathrm{g} / \mathrm{mL}$ to $0.97 \mu \mathrm{g} / \mathrm{mL}$ ) in 
a culture medium with final volume of $200 \mu \mathrm{L}$ and each well was seeded with a $50 \mu \mathrm{L}$ microbial suspension of 0.5 MacFarland density. In each test a microbial culture control and a sterility control (negative) were prepared. The plates were incubated for 24 hours at $37{ }^{\circ} \mathrm{C}$. The lowest concentration which inhibited the visible microbial growth was considered the MIC $(\mu \mathrm{g} / \mathrm{mL})$ value for the tested compound. The minimum inhibitory concentration (MIC) values are presented in Table 3.

\subsubsection{Cytotoxicity (MTT Assay)}

The cell viability (MTT test) of the different test compounds was assessed following our earlier published literature (Kalpana et al., 2018). To describe briefly: non-cancerous mammalian cells, CHOK1 - ATCC ${ }^{\circledR}$ CCL-61 ${ }^{\mathrm{TM}}$ (Chinese hamster ovary cells) collected from The Centre for Cellular and Molecular Biology (CSIR-CCMB), Hyderabad, India and Cancer cell lines such as HeLa: Cervical cancer (ATCC ${ }^{\circledR}$ CCL2), B16-F10: Mouse skin melanoma $\left(\mathrm{ATCC}^{\circledR}{ }^{\circledR}\right.$ CRL 6475 ${ }^{\mathrm{TM}}$ ), SKOV3: Human ovarian cancer (ATCC ${ }^{\circledR}$ HTB 77 TM ), MCF7: Human breast adenocarcinoma (ATCC ${ }^{\circledR}$ HTB-22 $^{\text {TM }}$ ) were obtained from ATCC (Bethesda, MD, USA). The cells were maintained in DMEM supplemented with $10 \%$ FBS, $2 \mathrm{mM}$ L-glutamine, $100 \mathrm{U} / \mathrm{mL}$ penicillin, and $100 \mu \mathrm{g} / \mathrm{mL}$ streptomycin at $37{ }^{\circ} \mathrm{C}$ in a $5 \%$ $\mathrm{CO} 2$ incubator. The cultured cells were loaded into 96-well culture plate and allowed to attach properly. Each test compound of different concentrations ranging from $1-50 \mu \mathrm{M}$ was treated in triplicate and incubated for $24 \mathrm{~h}$. Doxorubicin for cancer cells and Mitomycin $\mathrm{C}$ for $\mathrm{CHO}$ cells were used as standard drugs for comparison. Then, $0.5 \mathrm{mg} / \mathrm{mL}$ of 3-(4,5-dimethyl-2-thiazolyl)- 2,5-diphenyl-2Htetrazolium bromide (MTT) were added and incubated for $3 \mathrm{~h}$. To each well, DMSO $(100 \mu \mathrm{L})$ was added to dissolve the insoluble formazan crystals and the absorbance of the plates was measured using a Synergy H1Multi- Mode Plate Reader, USA.

\subsection{Statistical analysis}

Statistical analysis was carried out using Graph Pad Prism version 6.04 for Windows, Graph Pad Software, San Diego. The data were analyzed with unpaired Student's t-test, followed by "One-way ANOVA" by the Dunnett's multiple comparisons test.

\section{RESULTS AND DISCUSSION}

\subsection{Synthesis of 1-MAGs of unsaturated fatty acids}

This study was intended to evaluate the antimicrobial and cytotoxic behavior of the 1-monoacylglycerols of selected unsaturated fatty acids.
Among the selected fatty acids, GLA and ALA were obtained from urea complexation from borage and eri silkworm oils, respectively, whereas other fatty acids were commercially available. Eri silkworm oil and borage oil are reported to contain high amounts of ALA and GLA, respectively, and hence were taken as source oils for PUFAs. Urea complexation was carried out repeatedly to obtain maximum enrichment of the unsaturated fatty acids in the study. Ricinoleic acid was obtained from castor oil in pure form by selective extraction of hydroxy fatty acid using hexane and aqueous methanol solvent mixtures. Table 1 shows the composition of the initial and enriched fractions of unsaturated fatty acids.

It can be observed that in both silkworm and borage oils, the PUFA fraction was selectively enriched with urea complexation, which is usually the method of choice for PUFA concentration (Hayes et al., 1998). For the enrichment of ricinoleic acid, solvent fractionation was found to be the best and simplest method as it involved the partitioning of methyl ricinoleate in an aqueous methanol and hexane solvent mixture.

The synthesis of 1-monoacylglycerols of unsaturated fatty acids in the present study was carried out in two steps. Initially the fatty acids were esterified to solketal employing DCC as the coupling reagent and DMAP as the catalyst, which is a wellknown methodology for esterification (Yang et al., 2012) at ambient temperatures to obtain the respective acetonides at $45-82 \%$ yields (Figure 1). Solketal is a readily available reagent commercially. Since our aim is to prepare 1-monoacyl glycerol, the esterification of fatty acids with solketal and deprotection of acetonide formed from fatty acid-solketal reaction yields the desired 1-monoacyl glycerol with no byproducts. Therefore, we have employed solketal as one of the substrates.

As fatty acids like ALA and GLA were enriched in their methyl ester form, an enzymatic transesterification route was found to be more suitable to avoid the hydrolysis of methyl esters and subsequent chemical esterification steps. This has not only reduced the number of steps but also provided an opportunity to include an enzymatic step which was a simple, mild and green methodology. The lipase employed for this transesterification was an immobilized lipase from Candida antarctica which is well known for its esterification and transesterification activities in organic media (Adlercreutz 2013). Similarly, ricinoleic acid which is known to be unstable at ambient temperature was also enriched in its methyl ester form which was transesterified with solketal using lipase to obtain the corresponding acetonide (Figure 2) at a good yield. In the subsequent step, the acetonides were hydrolyzed in the presence of aqueous $\mathrm{HCl}$ at ambient temperature to obtain corresponding monoacylglycerols at $71-80 \%$ yields. 
Synthesis, characterization and evaluation of 1- monoacylglycerols of unsaturated fatty acids as potential bioactive lipids $\bullet 7$

TABLE 1. Fatty acid composition (wt $\%$ ) of substrate oils and their enriched fractions

\begin{tabular}{lcccccc}
\hline Fatty acid & SWO & $\begin{array}{c}\text { ALA-rich fraction } \\
\text { from SWO }\end{array}$ & Borage oil & $\begin{array}{c}\text { GLA-rich fraction } \\
\text { from Borage oil }\end{array}$ & Castor oil & $\begin{array}{c}\text { Ricinoleic acid-rich } \\
\text { fraction from castor oil }\end{array}$ \\
\hline $14: 0$ & $0.3 \pm 0.06$ & - & - & - & - & - \\
$16: 0$ & $24.9 \pm 0.94$ & - & $10.0 \pm 0.03$ & - & $1.3 \pm 0.33$ & - \\
$16: 1$ & $1.3 \pm 0.16$ & - & $0.1 \pm 0.01$ & - & - & - \\
$18: 0$ & $3.8 \pm 0.31$ & - & $4.2 \pm 0.03$ & - & $1.2 \pm 0.32$ & - \\
$18: 1$ & $13.2 \pm 0.27$ & $1.1 \pm 0.01$ & $17.0 \pm 0.07$ & - & $4.3 \pm 1.01$ & $0.3 \pm 0.03$ \\
$18: 2$ & $4.2 \pm 0.04$ & $4.7 \pm 0.13$ & $37.3 \pm 0.09$ & $4.1 \pm 0.09$ & $5.0 \pm 0.42$ & $0.4 \pm 0.04$ \\
$18: 1-O$ & - & - & - & - & $88.2 \pm 2.08$ & $99.3 \pm 0.07$ \\
$18: 3-\mathrm{A}$ & $51.6 \pm 0.57$ & $94.1 \pm 0.13$ & $0.3 \pm 0.04$ & $1.3 \pm 0.06$ & - & - \\
$18: 3-\mathrm{G}$ & - & - & $22.4 \pm 0.03$ & $94.6 \pm 0.04$ & - & - \\
$20: 0$ & - & - & $0.2 \pm 0.01$ & - & - & - \\
$20: 1$ & - & - & $4.1 \pm 0.06$ & - & - & - \\
$22: 0$ & - & - & $0.2 \pm 0.01$ & - & - & - \\
$22: 1$ & - & - & $2.6 \pm 0.05$ & - & - & - \\
$24: 0$ & - & $1.5 \pm 0.01$ & - & -
\end{tabular}

SWO: silkworm oil; ALA: alpha linolenic acid: GLA: gamma linolenic acid \pm , Standard deviation of mean value of triplicates using Graph Pad Prism software

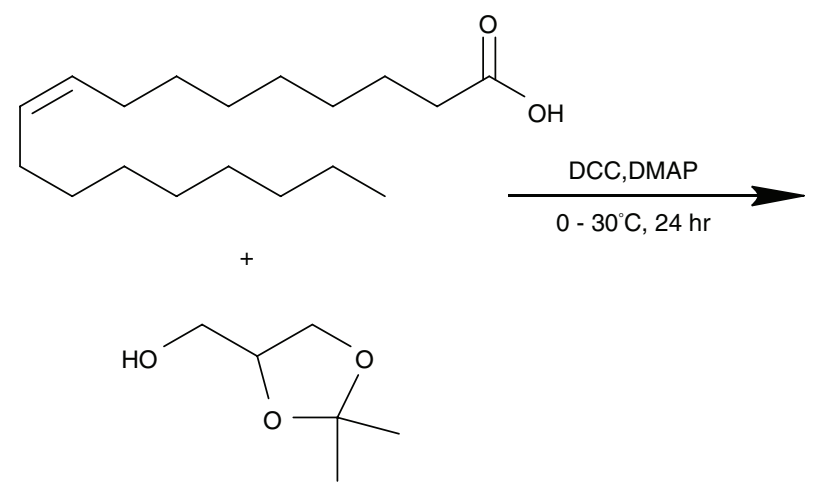

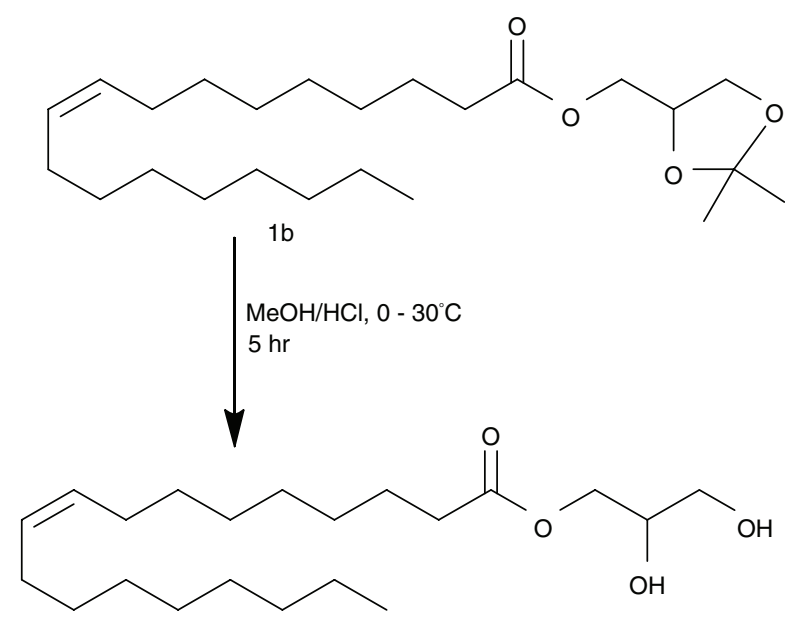

$2 b$

FIGURE 1. Synthetic route for 1-monoolein.

The procedures using DCC/DMAP for esterification and the hydrolysis of acetonide with $\mathrm{HCl}$ were mild and the yields were also satisfactory. The products of esterification and deprotection were purified by column chromatography and characterized by IR, NMR and mass spectral data. The structures of the prepared 1-MAGs are shown in Figure 3.

\subsection{Biological activity}

The synthesized 1-MAGs were subjected to antimicrobial evaluation against both bacterial and fungal strains and also for cytotoxicity assay against five cell lines. It was found that the MAGs showed antibacterial action but were not found to exhibit antifungal activity. The antibacterial activity was tested against both Gram-positive and Gram-negative bacterial strains. The results of the antibacterial activity were measured as zone of inhibition (in $\mathrm{mm}$ ) and are presented in Table 2. The Gram-positive strains used in the study were Staphylococcus aureus, Staphylococcus epidermidis, Bacillus subtilis and the Gram-negative strains were Escherichia coli, Pseudomonas aeroginosa and Klebsiella pneumonia. Penicillin and streptomycin were used as standard reference antibiotic 


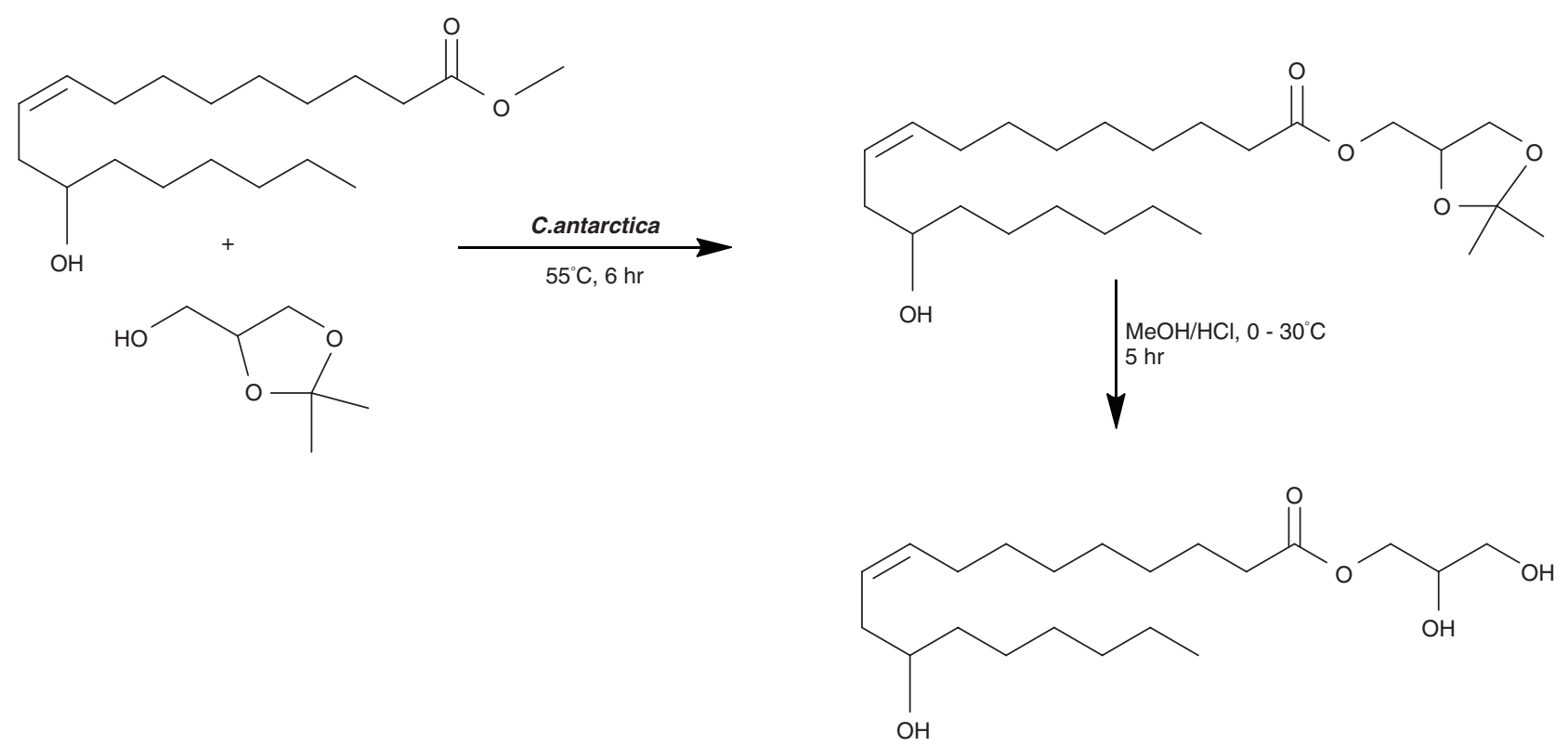

Figure 2. Synthetic route for 1-monoricinolein.

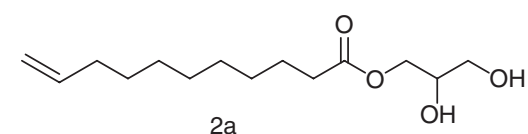

$2 a$

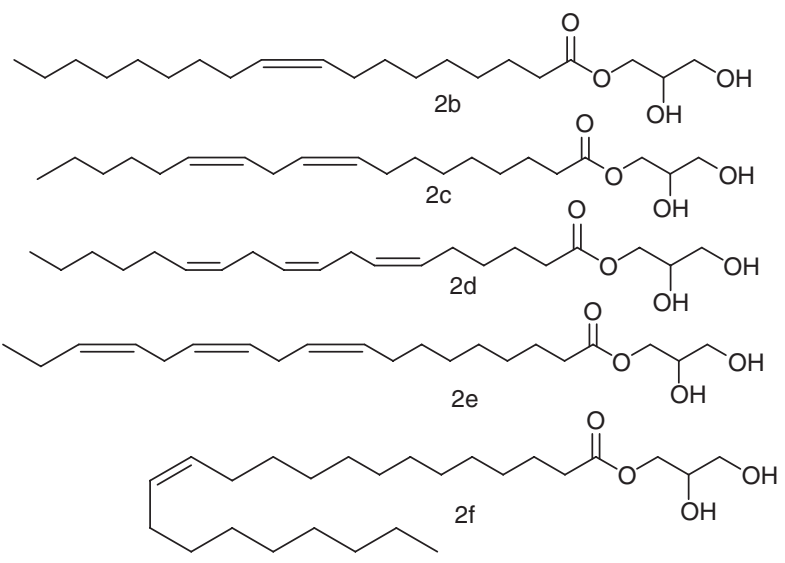<smiles>CCCCCCCCCCC(=O)OCC(O)CO</smiles>

FIGURE 3. Structures of the 1-monoacylglycerols.

compounds and 1-monolaurin was used as lipidic reference.

It was observed that most of the prepared 1-MAGs were more effective against Gram-positive bacteria compared to Gram-negative bacteria. Among the lipids, GLA-MAG showed a broad spectrum antibacterial activity against all the tested strains except against Klebsiella pneumonia. When analyzing the susceptibility of the lipids against various bacterial strains according to zone of inhibition, GLA-MAG against Staphylococcus aureu; ALA-MAG against Bacillus subtilis and ErucicMAG against Staphylococcus epidermidis exhibited higher antimicrobial action. To further investigate the efficacy of the prepared MAGs, minimum inhibitory concentration (MIC in $\mu \mathrm{g} / \mathrm{mL}$ ) was also determined (Table 3).

After the MAG of GLA, the next active MAG was observed to be of ALA, which showed inhibition against Staphylococcus aureus and Bacillus subtilis with MIC values of 37.5 and $9.37 \mu \mathrm{g} / \mathrm{mL}$, respectively. It was noted that the MAG of ricinoleic acid showed moderate activity against Staphylococcus aureus. In this study, the MAG of undecenoic acid was found to be active against two Gram-positive and one Gram-negative bacterial strains. The MIC value of UDA-MAG against Staphylococcus aureus in the present study was $150 \mu \mathrm{g} / \mathrm{mL}$, which was comparable to the value determined in a previously reported study (Dolezalova et al., 2010). It was reported that undecenoic acid was better known for its antifungal activity rather than antibacterial activity (Marijke and Stevens 2009). However, in the present study, it was found that MAGs with longer fatty acid chains were more effective compared to MAGs of undecenoic acid in terms of zone of inhibition. Earlier studies also reported that an increase in unsaturation of long-chain fatty acids has a positive effect on the antimicrobial action of fatty acids compared to saturated and shorter-chain fatty acids (Thormar and Hilmarsson 2007). It was interesting to observe that the MAG of erucic acid was active only against Staphylococcus epidermidis along with the MAG of 
TABLE 2. Bacterial zone of inhibition (mm) of test compounds

\begin{tabular}{lcccccc}
\hline Name of the Compound with code & $\begin{array}{c}\text { Staphylococcus } \\
\text { aureus }\end{array}$ & $\begin{array}{c}\text { Staphylococcus } \\
\text { epidermidis }\end{array}$ & $\begin{array}{c}\text { Bacillus } \\
\text { subtilis }\end{array}$ & $\begin{array}{c}\text { Escherichia } \\
\text { coli }\end{array}$ & $\begin{array}{c}\text { Pseudomonas } \\
\text { aeruginosa }\end{array}$ & $\begin{array}{c}\text { Klebsiella } \\
\text { pneumoniae }\end{array}$ \\
\hline $\begin{array}{l}\text { 1-Monolaurin (lipid reference } \\
\text { standard) }\end{array}$ & $15.8 \pm 0.7$ & - & $18.8 \pm 0.7$ & $15 \pm 1$ & $18.33 \pm 0.5$ & - \\
2a (UDA-MAG) & $11 \pm 0.5^{\mathrm{a}}$ & - & $8 \pm 1^{\mathrm{a}}$ & - & $19.66 \pm 0.5^{\text {ns }}$ & - \\
2b (Oleic-MAG) & - & - & - & - & - & - \\
2c (Linoleic-MAG) & - & - & - & - & - & - \\
2d (GLA-MAG) & $18.6 \pm 0.5^{\mathrm{a}}$ & $19.16 \pm 0.2^{\mathrm{b}}$ & $22.5 \pm 0.5^{\mathrm{a}}$ & $18.6 \pm 0.5^{\mathrm{a}}$ & $20.33 \pm 1.1^{\mathrm{c}}$ & - \\
2e (ALA-MAG) & $16.8 \pm 0.2^{\mathrm{ns}}$ & - & $20.8 \pm 0.2^{\mathrm{c}}$ & - & - & - \\
2f (Erucic-MAG) & - & $20 \pm 0.5^{\mathrm{b}}$ & - & - & - & - \\
2g (Ricinoleic-MAG) & $11.6 \pm 0.5^{\mathrm{a}}$ & - & - & - & - & - \\
Penicillin (standard) & $28 \pm 0.2^{\mathrm{a}}$ & $25.83 \pm 0.28$ & $27.6 \pm 0.5^{\mathrm{a}}$ & $24.16 \pm 0.7^{\mathrm{a}}$ & $23.16 \pm 0.28^{\mathrm{a}}$ & $25.33 \pm 0.5$ \\
Streptomycin & $22.8 \pm 0.2^{\mathrm{a}}$ & $25.16 \pm 0.2$ & $24 \pm 1^{\mathrm{a}}$ & $23.3 \pm 0.5^{\mathrm{a}}$ & $27.33 \pm 0.5^{\mathrm{a}}$ & $26.16 \pm 0.2$ \\
\hline
\end{tabular}

\pm , Mean value with standard error of mean of triplicates; "One-way ANOVA" used to measure the mean differences among the compounds by the Dunnett's multiple comparisons test. ${ }^{a}$ Significantly different from (lipid reference standard, 1-Monolaurin) at $\mathrm{P}<0.001 ;{ }^{\mathbf{b}}$ Significantly different from Penicillin at $\mathrm{P}<0.001$; ${ }^{\mathrm{c}}$ Significantly different from (lipid reference standard, 1 -Monolaurin) at $\mathrm{P}<0.05 ;{ }^{\mathrm{ns}}$ notsignificant

TABLE 3. Minimum Inhibitory Concentration $(\mu \mathrm{g} / \mathrm{mL})$ of test compounds

\begin{tabular}{|c|c|c|c|c|c|c|}
\hline Compound & $\begin{array}{c}\text { Staphylococcus } \\
\text { aureus }\end{array}$ & $\begin{array}{c}\text { Staphylococcus } \\
\text { epidermidis }\end{array}$ & $\begin{array}{l}\text { Bacillus } \\
\text { subtilis }\end{array}$ & $\begin{array}{c}\text { Escherichia } \\
\text { coli }\end{array}$ & $\begin{array}{c}\text { Pseudomonas } \\
\text { aeruginosa }\end{array}$ & $\begin{array}{c}\text { Klebsiella } \\
\text { pneumoniae }\end{array}$ \\
\hline 2a (UDA-MAG) & 150 & $>150$ & 150 & $>150$ & 9.37 & $>150$ \\
\hline 2b (Oleic-MAG) & $>150$ & $>150$ & $>150$ & $>150$ & $>150$ & $>150$ \\
\hline 2c (Linoleic-MAG) & $>150$ & $>150$ & $>150$ & $>150$ & $>150$ & $>150$ \\
\hline 2d (GLA-MAG) & 18.75 & 37.5 & 4.74 & 37.5 & 9.37 & $>150$ \\
\hline 2e (ALA-MAG) & 37.5 & $>150$ & 9.37 & $>150$ & $>150$ & $>150$ \\
\hline 2f (Erucic-MAG) & $>150$ & 9.37 & $>150$ & $>150$ & $>150$ & $>150$ \\
\hline 2g (Ricinoleic-MAG) & 150 & $>150$ & $>150$ & $>150$ & $>150$ & $>150$ \\
\hline 1-Monolaurin & 37.5 & $>150$ & 18.75 & 37.5 & 18.75 & $>150$ \\
\hline \multicolumn{7}{|l|}{ Standard Drug } \\
\hline Penicillin & 1.562 & 3.125 & 1.562 & 12.5 & 12.5 & 6.25 \\
\hline Streptomycin & 6.25 & 3.125 & 6.25 & 6.25 & 1.562 & 3.125 \\
\hline
\end{tabular}

Media values are represented in $\mu \mathrm{g} / \mathrm{mL}$ of serial dilution of two replicates. For all the test compounds, the highest concentration was used at $150 \mu \mathrm{g} / \mathrm{mL}$ and lowest concentration used at $2.34 \mu \mathrm{g} / \mathrm{mL}$; whereas, for standards (Penicillin and Strepotomycin) the highest concentration used at $100 \mu \mathrm{g} / \mathrm{mL}$ and lowest concentration at $0.78 \mu \mathrm{g} / \mathrm{mL}$. Values with $>150$ are considered to show no antibacterial activity.

GLA and no other MAG was effective against this bacteria, including monolaurin. The MIC value of the MAG of erucic acid was $9.37 \mu \mathrm{g} / \mathrm{mL}$, whereas GLA-MAG showed an MIC of $37.5 \mu \mathrm{g} / \mathrm{mL}$, which indicated that a very long-chain monounsaturated fatty acid was selectively active on this strain. In this study, GLA-MAG was observed to be the most active compound among all the MAGs tested. As monolaurin is the most widely known antimicrobial compound, we tried to compare the antimicrobial properties of the prepared MAGs with monolaurin. It was found that the MAG of GLA was more effective than 1-monolaurin against all the strains where monolaurin showed activity. Both zones of inhibitions and the MIC values of GLA-MAG were better than monolaurin. It was found that GLA-MAG was the most potent MAG against Bacillus subtilis with a MIC value of $4.74 \mu \mathrm{g} / \mathrm{mL}$, which was better than standard streptomycin which showed an MIC value of $6.25 \mu \mathrm{g} / \mathrm{mL}$. Many studies conducted earlier also reported similar observations where several antimicrobial lipids were shown to exhibit greater activity against Gram-positive bacteria species over Gram-negative species (Yoon et al., 2018). Against Gram-negative bacteria viz Pseudomonas aeruginosa, both GLA-MAG and UDA-MAG showed a 
TABLE 4 . in vitro cytotoxicity test of compounds $(\mu \mathrm{M})$ against cancerous and non-cancerous cell lines

\begin{tabular}{llccccc}
\hline & & \multicolumn{5}{c}{ IC50 values $(\boldsymbol{\mu M})$} \\
\cline { 3 - 7 } S.No & Test compound & HeLa & B16-F10 & SKOV3 & MCF-7 & CHO-K1 \\
\hline 1 & 2a (UDA-MAG) & $35.62 \pm 0.20$ & $42.12 \pm 0.08$ & $31.10 \pm 0.18$ & $15.32 \pm 0.05$ & $73.29 \pm 2.2$ \\
2 & 2b (Oleic-MAG) & $28.35 \pm 0.28$ & $97.36 \pm 0.10$ & $21.89 \pm 0.08$ & $23.03 \pm 0.01$ & $30.03 \pm 1.7$ \\
3 & 2c (Linoleic-MAG) & $32.13 \pm 0.15$ & $45.25 \pm 0.96$ & $27.34 \pm 0.85$ & $16.60 \pm 0.11$ & $43.32 \pm 0.28$ \\
4 & 2e (ALA-MAG) & $27.54 \pm 0.38$ & $44.04 \pm 0.15$ & $53.53 \pm 2.2$ & $16.42 \pm 0.21$ & $39.93 \pm 0.23$ \\
5 & 2d (GLA-MAG) & $25.55 \pm 0.58$ & $62.93 \pm 0.83$ & $26.75 \pm 0.10$ & $13.32 \pm 0.15$ & $28.97 \pm 0.27$ \\
6 & 2f (Erucic-MAG) & $23.98 \pm 0.79$ & $52.96 \pm 0.72$ & $44.65 \pm 0.60$ & $13.91 \pm 0.01$ & $51.61 \pm 0.12$ \\
7 & 2g (Ricinoleic-MAG) & $24.61 \pm 0.37$ & $99.20 \pm 2.0$ & $20.55 \pm 0.77$ & $15.60 \pm 0.07$ & $33.02 \pm 0.44$ \\
8 & 1-Monolaurin & $25.60 \pm 0.15$ & $69.79 \pm 1.3$ & $31.35 \pm 0.03$ & $15.64 \pm 0.06$ & $50.25 \pm 1.3$ \\
Standard Drug- Doxorubicin & $0.8 \pm 0.71$ & $0.7 \pm 0.56$ & $0.8 \pm 0.63$ & $2.0 \pm 0.81$ & NA \\
Mitomycin C & NA & NA & NA & NA & $13.1 \pm 0.68$ \\
\hline
\end{tabular}

Cancer cell lines: (HeLa, Homo sapiens cervix adenocarcinoma; B16-F10, Mouse skin melanoma (ATCC ${ }^{\circledR}$ CRL $^{6475}{ }^{\mathrm{TM}}$ ); SKOV3, Human Ovarian cancer (ATCC ${ }^{\circledR}$ HTB $77^{\mathrm{TM}}$ ); MCF7, Human Breast Adenocarcinoma (ATCC ${ }^{\circledR}$ HTB-22 $2^{\mathrm{TM}}$ ); Non-cancerous cell lines (CHO-K1, Chinese Hamster Ovary cells (ATCC ${ }^{\circledR}$ CCL-61 ${ }^{\mathrm{TM}}$ ); \pm , Standard deviation of mean value of triplicates using Graph Pad Prism software; NA, no activity.

MIC value of $9.37 \mu \mathrm{g} / \mathrm{mL}$, which is better than one of the standard antibiotic penicillins which showed a MIC of $12.5 \mu \mathrm{g} / \mathrm{mL}$. Against E. coli, only GLAMAG exhibited moderate activity with a MIC of $37.5 \mu \mathrm{g} / \mathrm{mL}$, which was comparable to monolaurin but lower than both standard antibiotics. It was also found that monolaurin was not active against Staphylococcus epidermidis whereas GLA-MAG and erucic-MAG showed better activity against this strain compared to monolaurin with MIC values of 37.5 and $9.37 \mu \mathrm{g} / \mathrm{mL}$, respectively.

The cytotoxicity evaluation for the prepared MAGs was carried out by the widely employed MTT assay and the results are presented in Table 4. From the cytotoxicity assay, it can be observed that all of the MAGs were found to show moderate activity compared to the standard drug. However, the MAGs showed better activity against MCF-7 cell lines compared to the other cell lines. Each MAG showed different activity against different cell lines. According to their $\mathrm{IC}_{50}$ values, it was found that erucic-MAG showed the highest activity against HeLa, ALA-MAG against B16-F10, ricinoleic-MAG against SKOV3, GLA-MAG against MCF-7 and the oleic MAG against CHO-K1.

The present study was helpful in assessing the antimicrobial and cytotoxicity potential of the 1-MAGs of some of the unsaturated fatty acids and further studies on a range of 1-MAGs of different fatty acids could be of interest in view of developing biocompatible biologically active agents.

\section{CONCLUSIONS}

The synthesis of structured 1-monoacylglycerols comprising unsaturated fatty acids and their antimicrobial and cytotoxicity efficacies were studied.
Among the prepared lipid derivatives, the monoacylglycerol of gamma linolenic acid was found to be the most effective against both Gram-positive and Gram-negative bacterial strains. All the MAGs prepared exhibited moderate cytotoxicity activity against a panel of cell lines. However, further studies are needed to exploit the full potential of these monoacylglycerol derivatives with different types of fatty acids to test in food-based systems for additional applications.

\section{ACKNOWLEDGMENTS}

Ms Juliya Johny and Dr. Shiva Shanker Kaki gratefully acknowledge the Science and Engineering Research Board, Department of Science \& Technology, New Delhi, for financial assistance under the Early Career Research Award [project file number ECR12017/000639] and the Director, CSIR-IICT, for providing the facilities.

IICT Communication number: IICT/Pubs./ $2018 / 291$

\section{REFERENCES}

Aarti N, Louk ARMP, Potts RO, Guy RH. 1995. Mechanism of oleic acid-induced skin penetration enhancement in vivo in humans. J. Cont. Release 37, 299-306. https://doi. org/10.1016/0168-3659(95)00088-7

Adlercreutz P. 2013. Immobilisation and application of lipases in organic media. Chem. Soc. Rev. 42, 6406-6436. https:// doi.org/10.1039/C3CS35446F

Altieri C, Bevilacqua A, Cardillo D, Sinigaglia M. 2009. Effectiveness of fatty acids and their monoglycerides against gram-negative pathogens. Int. J. Food Sci. Technol. 44, 359-366. https://doi.org/10.1111/j.1365-2621.2008.01744.x

Berdeaux O, Christie WW, Gunstone FD, Sebedio JL. 1997. Large-scale synthesis of methyl cis-9,trans-11-octadecadienoate from methyl ricinoleate. J. Am. Oil Chem. Soc. 74, 1011-1015. https://doi.org/10.1007/s11746-997-0018-z 
Bornscheuer UT. 1995. Lipase-Catalyzed Syntheses of Monoglycerols. Enzyme Microb. Technol. 17, 578-586. https://doi.org/10.1016/0141-0229(94)00096-A

Christie, WW. 1982. The preparation of derivatives of lipids. Lipid Analysis, 2nd ed.; Pergamon Press Ltd.: Oxford, United Kingdom, pp 51-61.

Clinical and Laboratory Standards Institute. 2008. Performance Standards for Antimicrobial Susceptibility Tests; Eighteen informational supplement M100-S18.

Desbois AP, Lawlor KC. 2013. Antibacterial activity of longchain polyunsaturated fatty acids against Propionibacterium acnes and Staphylococcus aureus. Mar. Drugs 11, 4544 4557. https://doi.org/10.3390/md11114544

Dolezalova M, Janis R, Svobodova H, Kasparkova V, Humpolicek P, Krejci J. 2010. Antimicrobial properties of 1-monoacylglycerols prepared from undecanoic (C11:0) and undecenoic (C11:1) acid. Eur. J. Lipid Sci. Technol. 112, 1106-1114. https://doi.org/10.1002/ejlt.200900295

Flider FJ. 2005. GLA: Uses and new sources. INFORM 16, 279-282.

Hayes DG, Bengtsson YC, Van Alstine JM, Setterwall F. 1998. Urea complexation for the rapid, ecologically responsible fractionation of fatty acids from seed oil. J. Amer. Oil Chem. Soc. 75, 1403-1409. https://doi.org/10.1007/ s11746-998-0190-9

Kabara JJ, Marshall DL. 2005. Medium-chain fatty acids and esters, in Davidson PM, Sofos JN, Branen AL. (Eds.). Antimicrobials in Food. CRC Press, Boca Raton, USA, pp. 327-360.

Kabara JJ, Swieczkowski DM, Conley AJ, Truant JP. 1972. Fatty acids and derivatives as antimicrobial agents. Antimicrob. Agents Chemother. 2, 23-28.

Kaki SS, Ravinder T, Ashwini B, Rao BVSK, Prasad RBN 2014. Enzymatic modification of phosphatidylcholine with n-3 PUFA from silkworm oil fatty acids. Grasas Aceites $\mathbf{6 5}$, e021. https://doi.org/10.3989/gya.097213

Kalpana J, Gousia B, Shruti SD, Rohit RK, Sunil M. 2018. Potential of the bioinspired $\mathrm{CaCo} 3$ microspheres loaded with tetracycline in inducing differential cytotoxic effects toward noncancerous and cancer cells: a cytogenetic toxicity assessment using $\mathrm{CHO}$ cells in vitro. Chem. Res. Toxicol. 31, 629-636. https://doi.org/10.1021/acs. chemrestox. 8 b00131

Linday ME. 1962. Practical Introduction to Microbiology. E and F.N. Spon Ltd., United Kingdom, p. 177.

Littich R. 2017. Antimicrobial lipids: attenuating the use of medically important antimicrobial drugs in food-producing animals: What role Can cGMP lipids play? Drug Dev. Del. 17, 56-61.

Lu W, Kelly Al, Miao S. 2017. Improved bioavailability of encapsulated bioactive nutrients delivered through monoglyceride-structured o/w emulsions. J. Agric. Food Chem. $\mathbf{6 5}, 3048-3055$. https://doi.org/10.1021/acs.jafc.6b05644
Maryam SF, Ming D, Pan A, Sun Q, Stephanie EC, Lyn MS, Walter CW, Hu FB. 2014. Dietary linoleic acid and risk of coronary heart disease: a systematic review and metaanalysis of prospective cohort studies. Circulation 130, 1568-1578. https://doi.org/10.1161/CIRCULATIONAHA. 114.010236

Nguemeni C, Gouix E, Bourourou M, Heurteaux C, Blondeau N. 2013. Alpha-linolenic acid: A promising nutraceutical for the prevention of stroke. Pharm. Nutrition 1, 1-8. https://doi.org/10.1016/j.phanu.2012.12.002

Osborn HT, Akoh, CC. 2002. Structured lipids - Novel fats with medical, nutraceutical and food applications. Compr. Rev. Food Sci. Food Saf. 3, 110-120. https://doi. org/10.1111/j.1541-4337.2002.tb00010.x

Pabiś S, Kula J. 2016. Synthesis and bioactivity of (r)-ricinoleic acid derivatives: A review. Curr. Med. Chem 23, 4037-4056. https://doi.org/10.2174/0929867323666160627104453

Pawongrat R, Xu X, Kittikun AH. 2008. Physico-enzymatic production of monoacylglycerols enriched with very-longchain polyunsaturated fatty acids. J. Sci. Food Agric. 88, 256-262. https://doi.org/10.1002/jsfa.3081

Pierard GE, Arrese JE, Pierard-Franchimont C, De Doncker P. 1997. Prolonged effects of anti-dandruff shampoos - time to recurrence of Malassezia ovalis colonisation of skin. Int. J. Cosmet. Sci. 19, 111-117. https://doi.org/10.1111/j.1467-2494.1997. tb00174.x

Janis R, Krejcí J, Klásek A. 2000. Preparation of 1-monoacylglycerols from glycidol and fatty acids catalyzed by the chromium(III)- fatty acid system. Eur. J. Lipid Sci. Technol. 102, 351-354. https://doi.org/10.1002/(SICI)14389312(200005) 102:5<351::AID-EJLT351>3.0.CO;2-J

Sonntag NOV. 1982. Glycerolysis of fats and methylestersStatus, review and critique. J. Am. Oil Chem. Soc. 59, 795A-802A. https://doi.org/10.1007/BF02634442

Thormar H, Hilmarsson H. 2007. The role of microbicidal lipids in host defense against pathogens and their potential as therapeutic agents. Chem. Phys. Lipids 150, 1-11. https:// doi.org/10.1016/j.chemphyslip.2007.06.220

Yang D, Cwynar VA, Hart DJ, Madanmohan J, Lee J, Lyons J, Caffrey M. 2012. Preparation of 1-monoacylglycerols via the Suzuki-Miyaura reaction: 2, 3-dihydroxypropyl (Z)-tetradec-7-enoate. Org. Synth. 89, 183-201. https://doi. org/10.1002/0471264229.os089.19

Yoon BK, Jackman JA, Valle-González ER, Cho NJ. 2018. Antibacterial free fatty acids and monoglycerides: Biological activities, experimental testing, and therapeutic applications. Int. J. Mol. Sci. 19, 1114. https://doi. org/10.3390/ijms19041114

Zheng CJ, Jung-Sung Y, Tae-Gyu L, Hee-Young C, Young-Ho K, Won-Gon K. 2005. Fatty acid synthesis is a target for antibacterial activity of unsaturated fatty acids. FEBS Lett. 579, 5157-5162. https://doi.org/10.1016/j. febslet.2005.08.028 